\title{
Algumas considerações sobre a interdependência entre democracia e educação no pensamento ocidental
}

José Antônio Feitosa Apolinário
Professor da Universidade Federal Rural de Pernambuco
Diego Kehrle Souza

\section{Resumo}

O presente texto visa analisar de maneira introdutória como se constrói no decurso do pensamento filosófico ocidental a relação de interdependência entre democracia e educação, os argumentos que lhe dão sustentação, bem como as possíveis controvérsias de significação nela existentes. Para esse fim, examinamos obras fundamentais da filosofia e em específico da filosofia da educação, buscando compreender asserções de autores que implícita ou explicitamente tratam dessa articulação.

Palavras-Chave: Democracia; Educação; Formação.

\begin{abstract}
This text aims to analyze introductorily how is constructed the interdependence between democracy and education in the course of Western philosophical thought, the arguments that support it and the possible significance of controversies that exist within it. For this purpose, we examine fundamental works of philosophy and in particular the philosophy of education, seeking to understand assertions of authors what treated this joint implicitly or explicitly.
\end{abstract}

Keywords: Democracy. Education. Formation. 


\section{Introdução}

trabalho em voga é resultado de um exame que se propôs
inventariar de modo introdutório como foram concebidas em
certas paragens do discurso filosófico inter-relações possíveis entre democracia e educação, por meio de um diagnóstico crítico-reflexivo que tenta compreendê-las inclusive no sentido da contribuição destas à consolidação das instituições democráticas até a contemporaneidade. Para tanto, fez-se necessário ir às origens da questão, com base na leitura cronológica das transformações e implicações desta relação, tentando encontrar que elementos permanecem e quais aqueles que já saíram de cena nas discussões hodiernas.

Nessa direção, pesquisamos concepções de educação e democracia em alguns autores da filosofia, especialmente, articulações argumentativas entre as mesmas. Tentamos traçar por meio de análise os elementos de convergência e divergência dos autores estudados em torno da discussão em voga, com o intuito de aduzir uma interpretação sistematizada que sintetize elementos argumentativos válidos a uma noção de educação democrática sintonizada com as exigências de nosso tempo. Por opção metodológica, decidimos que seria imprescindível um retorno aos autores clássicos e modernos, como Aristóteles, Rousseau e Nietzsche, antes de nos debruçarmos sobre pensadores contemporâneos.

$\mathrm{Na}$ intenção de alcançar uma percepção histórico-filosófica de nosso objeto de pesquisa, decidimos seguir cronologicamente os conceitos naquilo que diz respeito às origens e transformações da relação entre democracia e educação. Destarte, dividimos o presente artigo em três momentos. No primeiro centramo-nos na análise das seguintes obras: Política de Aristóteles, Do Contrato Social e Emílio de Rousseau, e Além do Bem e do 
Mal de Nietzsche. Em seguida, realizamos o exame de noções extraídas de obras de autores situados no século XX: John Dewey, Joseph A. Schumpeter, Anísio Teixeira e Paulo Freire. Por fim, efetuamos algumas inferências e considerações em torno de nosso desiderato investigativo. Doravante, apresentamos sínteses das leituras que tentam estabelecer um primeiro quadro de referências teóricas acerca destas relações dentro da tradição filosófica ocidental.

\section{Democracia e educação na Política}

Além de sua teoria política, Aristóteles nos apresenta pelas páginas da Política, uma fisiopedagogia ${ }^{1}$. Ainda em seu início, nos é exposta a ideia de polis (cidade) como um organismo, onde as partes (homens e instituições) tem seu papel em função do todo (comunidade). Mas, esta relação, segundo Aristóteles, não é artificial, visto que o homem é um animal social por natureza, assim, quando este se une a outros homens para tornarem-se autossuficientes, por meio de uma espécie de união de comunidades menores, temos aquele que seria o último estágio destas (e, portanto, a natureza para a qual tendem): a comunidade política.

Tal comunidade não se forma apenas para ser autossuficiente, mas também para proporcionar aos homens felicidade, já que esta é condição para uma vida distinta. Para Aristóteles este modo superior de vida se dá quando as ações são regidas pelo pensamento, ou seja, quando aquelas ganham forma sob os ditames do intelecto e da moral. Neste sentido, em consequência de sua definição do homem como ser cindido, que possui um

1 Segundo Antoine Houdarkis, a educação em Aristóteles "não é considerada uma situação, mas uma atividade e uma força que produz uma obra política, social e moral" (2001, p. 16), é a partir de um envolvimento físico (do corpo) e psíquico (da alma) que a educação forma o homem. A obra em questão - Política - será referendada de acordo com a numeração standard do corpus aristotélico. 
lado racional e outro que é anterior ao primeiro, e por isso, desprovido de razão, ele insiste na necessidade de que se forjem leis que forneçam as diretrizes para uma educação essencialmente moral do homem (tornar prático aquilo que ele possui em potencial): [...] "é mais necessário igualizar os desejos dos homens que suas propriedades, e só se pode chegar a este resultado mediante um sistema adequado de educação imposto por lei" (ARISTÓTELES, 1985, 1267a).

Esta formação moral dará condições ao homem para que este passe de um estado em que suas ações são resultado da forma irracional do desejo para aquele em que estas decorrem da deliberação reflexiva, ou seja, daquele estado no qual ele é a causa ativa de suas próprias ações. Naturalmente, esta escolha 'voluntária' e racional se dá em concordância com aquelas qualidades que, de tão arraigadas através dos hábitos e costumes, se tornaram disposições da alma ${ }^{2}$. Destarte, é justamente a responsabilidade pelo processo de composição do caráter moral dos indivíduos, que Aristóteles delega à cidade (polis) quando define que a educação deve ser pública e regida por lei. Não obstante trate em outra obra (Ética a Nicômaco) da educação privada, quando se volta ao domínio político, o Estagirita irá sempre insistir no papel primordial que a educação tem para a estabilidade política da polis, pois é por meio dela que a cidade alcançará certa unidade. Assim, a educação passa a ser um instrumento político que tem como fim a continuidade de um determinado tipo de constituição, que pressupõe uma vida melhor para todos, ou dito de outro modo, o bem comum.

Como o próprio título nos lembra, de modo geral, a Política trata fundamentalmente sobre qual seria a melhor forma de governo

2 Cf. NEDERMAN, Cary J. The puzzle of the political animal: nature and artifice in Aristotle's political theory. The review of politics. South Bend, v. 56, n. 2, 1994. p. 288-290. 
(constituição) a ser adotada pela cidade. Quando Aristóteles constrói a análise do governo democrático, chega a enumerar quatro tipos de democracia que, apesar das diferenças ${ }^{3}$, podemos definir como tendo por princípios fundamentais: a liberdade, a soberania da maioria e a igualdade. Depois de dizer que o objetivo de toda democracia é a liberdade, ele ainda acrescenta:

mas um princípio de liberdade é governar e ser governado alternadamente, pois o conceito popular de justiça é a observância da igualdade baseada no princípio da maioria, e não no do mérito, e se este é o conceito de justiça dominante, a maioria deve ser necessariamente soberana, e a decisão da maioria deve ser final e constituir a justiça [...] (ARISTÓTELES, 1985, 1317b).

Ao longo do texto, o filósofo discorda da perspectiva da igualdade segundo o princípio da maioria, afirmando que a igualdade só deve existir para os iguais. Contudo, no momento, o que nos interessa é a relação entre os três elementos que sustentam a democracia. Este é o governo em que a maioria é soberana e participa da administração da cidade, e aqui entendemos como sendo maioria aquele grupo composto de homens livres, não importa se ricos ou pobres - os cidadãos (do gênero masculino, em uma condição etária adulta, em referência à democracia direta vivida na antiguidade grega, em Atenas). Como podemos observar no trecho acima, a liberdade é definida como possibilidade de participação política, deste modo, por todos os cidadãos possuírem direitos iguais, todos podem participar da vida política, esta participação (que pode esconder certa

3 São diferenças que dizem respeito à participação e soberania: no primeiro tipo de democracia apresentado é preciso possuir uma quantia mínima de bens, no segundo é preciso ser filho de cidadãos, no terceiro a lei é soberana e no quarto tipo as massas, através das assembleias são soberanas, não a lei.

Filosofia e Educação - ISSN 1984-9605

Volume 6, Número 2 - Junho de 2014 
'tirania da maioria') é que vai definir o que é justo a partir dos mecanismos jurídicos que estabelecem as leis. Mas a liberdade, nesta perspectiva, vai além destas práticas, pois ela não é apenas possibilidade de deliberar politicamente, significa também viver em conformidade com os preceitos constitucionais, ou seja, é agir politicamente e viver sob a força e os efeitos desta ação ${ }^{4}$.

Para que não se dependa apenas de leis impessoais, mas que estas sejam reflexo do modo de vida escolhido e praticado pela maioria, torna-se premente pensar um sistema educacional que forme cidadãos para uma vivência democrática, e isto com base no seguinte princípio: "como há um fim único para a cidade toda, é óbvio que a educação deve ser necessariamente uma só e a mesma para todos" (ARISTÓTELES, 1985, 1337a). Aristóteles permite-nos refletir aqui sobre o papel político da educação em uma cidade democrática: formar cidadãos virtuosos, de caráter democrático e que agem a partir de preceitos morais que tem como fim uma vida superior, o bem comum e a felicidade, que consiste em ser causa ativa de suas ações. Neste sentido, o Livro VIII da Política, aduz a estrutura deste programa educativo: trata das matérias (Gramática, Ginástica, Música e Desenho), enumera as etapas pelas quais o indivíduo passa ao longo do processo educacional, descrevendo aquilo que deve ser priorizado em cada etapa, para que, ao chegar à fase adulta, ele esteja formado não apenas moral

4 "[...] Viver de conformidade com preceitos constitucionais não é escravidão, mas salvação" (ARISTÓTELES, 1985, 1310a). Ao edificar a tese da liberdade enquanto inscrita originariamente no âmbito político, anterior à compreensão ulterior de uma 'liberdade interior', escreve Hannah Arendt: "o campo em que a liberdade sempre foi conhecida, não como um problema, é claro, mas como um fato da vida cotidiana, é o âmbito da política [...] ação e política, entre todas as capacidades e potencialidades da vida humana, são as únicas coisas que não poderíamos sequer conceber sem ao menos admitir a existência da liberdade, e é difícil tocar em um problema político particular sem, implícita ou explicitamente, tocar em um problema de liberdade humana" (ARENDT, 2011, p. 191/192). 
e intelectualmente, mas que, além disso, possua determinadas aptidões físicas.

A democracia descrita por Aristóteles é uma forma de governo que supõe uma sociedade bem ordenada, que apesar da insistência do autor na superioridade natural de uns sobre os outros, e, portanto, de diferenças, termina por propor através da educação, uma igualização dos homens, dos desejos e deveres em favor do todo, da polis. Por isso, para ele, a democracia não é uma forma de governo para cidades com muitos habitantes, pois estes devem conhecer-se e partilhar interesses, tendo como principal objetivo o bem comum. Segundo o Estagirita, tal desígnio seria impossível em cidades com grande número de cidadãos. Pelo exposto, o conceito aristotélico de democracia parece ecoar o sentido histórico apinhado às polis democráticas gregas, mormente Atenas, levando em conta a dimensão participativa dos homens livres que mediante educação tornamse aptos a esta forma de efetuação do exercício político.

\section{Soberania e educação em Rousseau}

Em Do Contrato Social, publicado em 1762, Jean-Jacques Rousseau comenta e analisa os diversos tipos de governos existentes - em exame análogo àquele feito por Aristóteles na Política - para, por fim, propor aquele que a seu ver é o mais coerente com uma 'associação' de homens livres e iguais.

Para Rousseau, o homem que vive fora de qualquer associação é livre desde que possua a força necessária para impor a sua vontade, logo, apesar da liberdade, não existem outras garantias para a vida ou para os seus bens, apenas a força. Para ele a associação entre os homens é o que garante a eles uma outra (e superior) forma de liberdade, pois os torna iguais a partir 
de um consenso (ou contrato) a que devem chegar os que decidem participar de tal associação, tornando esta legítima e de direito. Sendo assim, o objetivo de sua investigação é "encontrar uma forma de associação que defenda e proteja a pessoa e os bens de cada associado com toda a força comum, e pela qual cada um, unindo-se a todos, só obedece contudo a si mesmo, permanecendo assim tão livre quanto antes" (ROUSSEAU, 1991b, p. 32).

A liberdade aqui é convencional. Destarte, ao passar do estado de natureza para o estado civil, a conduta do homem não dependerá mais dos seus impulsos naturais, a razão e a moral tomam o lugar destes enquanto a força e os apetites são substituídos pelo direito e pelo dever. Por meio da liberdade civil, o pacto social garante ao homem a posse de seus bens e uma vida sob as leis que ele mesmo estatui. Em Rousseau, assim como em Aristóteles, a vida boa é aquela regida pela razão e por uma moral do coletivo, esta pode ser entendida por aquilo que as vontades particulares (de cada cidadão) possuem em comum, aqui chamada vontade geral.

Portanto, o pacto social de Rousseau tem como fim a criação deste espaço social e político, onde os homens têm seus direitos e deveres garantidos e estabelecidos por convenção. Esta estrutura ele assim define:

essa pessoa pública, que se forma, desse modo, pela união de todas as outras, tomava antigamente o nome de cidade e, hoje, o de república ou de corpo político, o qual é chamado por seus membros de Estado quando passivo; soberano quando ativo, e potência quando comparado a seus semelhantes. Quanto aos associados; recebem eles, coletivamente, o nome de povo e se chamam, em particular, cidadãos enquanto partícipes da autoridade soberana, súditos enquanto submetidos às leis do Estado (ROUSSEAU, 1991b, p. 33-34).

Ao aceitá-la, assim como ao regime político por ela estabelecido, o

Filosofia e Educação - ISSN 1984-9605

Volume 6, Número 2 - Junho de 2014 
cidadão deverá estar comprometido com os desígnios da vontade geral, sendo coagido a ser 'livre' caso se recuse a obedecer às leis vigentes. Em situações extremas como essa, podemos enxergar claramente os mecanismos que delimitam a liberdade civil: as leis instituídas são os mecanismos que asseguram a vida 'boa' e a liberdade dos cidadãos, assim, o ato de transgredi-las nega um dos princípios basilares de tal associação. Se consideramos que toda ação livre é regida por uma moral que a determina e por um poder que a executa, por qual motivo, segundo Rousseau, deve-se coagir o cidadão a ser livre, caso ele negue as leis do Estado? Justamente porque ao negá-las ele estará negando aquilo que ele mesmo estabeleceu (enquanto soberano) como fonte de suas ações (as leis); logo, estará renunciando também à sua liberdade. Ao observar este princípio no corpo político do Estado, Rousseau vai nos dizer que nele, a ação livre possui “os mesmos móveis. Distinguem-se nele a força e a vontade, esta sob o nome de legislativo e aquela, de poder executivo" (ROUSSEAU, 1991b, p. 73). É importante esclarecer que estes poderes são julgados, nesta senda, como emanações da soberania, pois ela não se divide. Noutras palavras, no legislativo a vontade geral é declarada e se faz lei, já o executivo é responsável pela aplicação dessa lei a casos particulares.

Tendo definido a estrutura que compõe o Estado, o filósofo passa a investigar a melhor forma de governo, aquela que garantiria o domínio da vontade geral sobre as vontades particulares. Antes de tratar da democracia, Rousseau esclarece que o governo que possui maior força é o que tem menor número de magistrados, pois nele a força necessária para exercer a soberania será maior e mais concentrada, já que depende de poucos e se dispersaria menos, assim, conclui que quanto maior o Estado, mais concentrado deve se tornar o poder executivo. Logo, dependendo do 
tamanho do Estado, uma dada forma de constituição será mais conveniente para governá-lo, e é assim que Rousseau infere que a democracia é conveniente a Estados menores.

Aqui, chegamos a um impasse que é considerado por Robert Dahl como o gerador de uma mudança na tradição Democrática ${ }^{5}$. Na polis grega, a questão do aumento do número de cidadãos se tornou problemática aos ideais democráticos, a partir de então, como todos os cidadãos se reuniriam para decidir soberanamente as questões da cidade? Com o crescimento das cidades, em número e tamanho, a sociedade que antes se dividia entre os interesses dos poucos ou aqueles da maioria, tornava-se uma sociedade progressivamente mais numerosa e com uma diversidade de interesses consequentemente maior, assim a chamada forma de governo 'republicana', esboçada já na ideia de governo constitucional de Aristóteles, ao mesclar elementos da democracia, aristocracia e monarquia, se torna uma espécie de conciliadora de discursos cada vez mais distintos. Porém, ainda nos resta a questão da soberania da maioria. Nestas condições, como todos poderiam continuar exercendo o seu direito de participação política? A resposta encontrada foi a eleição de representantes do povo, cidadãos que teriam a responsabilidade de deliberar no lugar de outros (a moderna democracia representativa). Sobre isto, Rousseau é taxativo em sua resposta:

é nula toda lei que o povo diretamente não ratificar; em absoluto, não é lei. O povo inglês pensa ser livre e muito se engana, pois só o é durante a eleição dos membros do parlamento; uma vez estes eleitos, ele é escravo, não é nada. Durante os breves momentos de sua liberdade, o uso, que dela faz, mostra que merece perdê-la (ROUSSEAU, 1991b, p. 108).

5 Cf. DAHL, Robert A. La Democracia y sus críticos. Barcelona: Ediciones Paidós Ibérica, 1992. p. 39.

Filosofia e Educação - ISSN 1984-9605

Volume 6, Número 2 - Junho de 2014 
Ele não acha solução para tal impasse, diz apenas que se a soberania romana existiu em um Estado tão vasto, a possibilidade existe, mas ele não apresenta reais métodos para tanto. Pelo contrário, o seu Estado ideal é pequeno, sem essa característica se torna impossível ao soberano conservar os direitos e a liberdade que o definem. Mesmo sem oferecer um modelo democrático aos grandes Estados modernos, através da sua definição de Democracia, o autor já deixava claro que a democracia verdadeira é praticamente impossível em tais proporções, somente sendo realizável em Estados possuidores de condições muito específicas (Estado pequeno, simplicidade de costumes, igualdade entre as classes e virtuosismo moral). Apesar disso, é importante perceber que o conceito rousseauniano de soberania de certa forma faz um apelo à participação do cidadão, independente da forma de governo. E, por outro lado, parece repetir a fórmula aristotélica ao defender a reafirmação contínua da soberania por parte do cidadão:

não basta que o povo reunido tenha uma vez fixado a constituição do estado sancionado um corpo de leis; não basta, ainda, que tenha estabelecido um governo perpétuo ou que, de uma vez por todas, tenha promovido a eleição dos magistrados; além das assembléias extraordinárias que os casos previstos podem exigir, é preciso que haja outras, fixas e periódicas, que nada possa abolir ou adiar, de tal modo que, no dia previsto, o povo se encontre legitimamente convocado pela lei, sem que para tanto haja necessidade de qualquer outra convocação formal (ROUSSEAU, 1991b, p. 104).

O cidadão, em Rousseau, é posicionado como elemento central do processo político, que tem a soberania como causa e fim; é através dele, enquanto ente coletivo, que a vontade geral se origina e de onde parte para dar forma, como soberano, às leis. É também numa relação inversa, 
enquanto parte do Estado e como súditos, que os cidadãos aceitam viver sob esta vontade transformada em direitos e deveres. É por esse papel fundamental no quadro político, traçado em seu Contrato Social, que Rousseau vai insistir na defesa da participação desta figura na vida política do Estado. No trecho podemos observar a medida desta consideração: "no momento em que o povo se encontra legitimamente reunido em corpo soberano, cessa qualquer jurisdição do Governo, suspende-se o poder executivo e a pessoa do último cidadão é tão sagrada e inviolável quanto a do primeiro magistrado", e arremata, "pois onde se encontra o representado não mais existe o representante" (ROUSSEAU, 1991b, p. 106).

Por outro lado, podemos dizer que, o povo que não participa ativamente do corpo político, diminui o poder do soberano sobre o governo, e este governa de acordo com seus interesses particulares. A relação original entre soberano e governo precisa ser constantemente reafirmada através da vida política dos cidadãos, e o governo deve exercer aquilo que foi estabelecido pela vontade geral através do soberano (pelo poder legislativo), disto se segue que, nas palavras de Rousseau, "os depositários do poder executivo não são senhores do povo, mas seus funcionários" (ROUSSEAU, 1991b, p. 113). É também nesse sentido que o pensamento rousseauniano promove uma conciliação entre democracia e república, na medida em que une o ideal clássico da soberania popular e o moderno ideal republicano, reivindicando-os à constituição das sociedades políticas de sua época ${ }^{6}$.

Nesta direção, nos arriscamos a intuir que para se chegar a este cidadão, política e moralmente virtuoso, o autor pressupunha uma educação que o formasse não apenas no sentido democrático, como prescrevia Aristóteles, mas também num sentido mais particular e individual, a fim de

6 Cf. BOBBIO, Norberto; MATTEUCCI, Nicola; PASQUINO, Gianfranco. Dicionário de política. 11 ed. Brasília: UNB, 1998. p. 319-329.

Filosofia e Educação - ISSN 1984-9605

Volume 6, Número 2 - Junho de 2014 
garantir a estabilidade do regime político não só por meio de leis, mas antes pela soberania do próprio cidadão, já que este não descansaria enquanto suas ações na vida pública não estivessem em consonância com as virtudes morais que garantissem o bem comum. É nesse sentido que se pode afirmar que "o projeto político de Rousseau é um projeto pedagógico" (VIEIRA, 1997, p. 108). No Emílio, obra em que Rousseau propõe o seu ideal de educação, ele analisa e descreve os preceitos e cuidados a serem dedicados ao estudante desde a infância até a fase adulta, sua formação moral, intelectual, afetiva e física são tratadas minuciosamente.

Em uma palavra, ensinai a vosso aluno a amar todos os homens, inclusive os que os desdenham; fazei com que ele não se coloque em nenhuma classe, mas que se encontre em todas; falai diante dele, e com ternura, do gênero humano, com piedade até, mas nunca com desprezo. Homem, não desonres o homem. (...) Nada de vaidade sobretudo, nada de emulação, nada de glória, nada de sentimentos que nos forçam a comparar-nos aos outros, pois tais comparações nunca se fazem sem alguma impressão de ódio contra os que nos disputam a preferência, ainda que somente em nossa própria estima (ROUSSEAU, 1995, p. 253).

Percebe-se aqui, a influência da doutrina cristã nas palavras do filósofo francês. Para ele a religião era necessária, e, mesmo quando recomenda a livre escolha religiosa sob os ditames da razão, ainda no Livro IV, ele deixa clara sua preferência ao descrever o seu encontro e convívio com um eclesiástico. Assim, a educação proposta no Emílio tem como fim o homem natural - considerado naturalmente $\mathrm{bom}^{7}$ - como aquele que possui

$7 \mathrm{Na}$ contramão da tese hobbesiana do estado de natureza do homem - o homem é naturalmente mau - Rousseau desenvolve uma tese oposta, partindo da piedade enquanto única virtude moral natural pertencente ao ser humano, anterior à própria condição reflexiva: "não creio ter a temer qualquer contradição, se conferir ao homem a única virtude natural que o detrator mais acirrados das virtudes humanas teria de reconhecer. Falo da piedade, disposição conveniente a seres tão fracos e sujeitos a tantos

Filosofia e Educação - ISSN 1984-9605

Volume 6, Número 2 - Junho de 2014 
uma sólida formação moral, baseada na observação e compreensão dos afetos e apetites do homem, não apenas daquele que é educado, mas, sobretudo, daqueles com os quais ele irá conviver em sociedade.

[...] Querendo formar um homem da natureza, nem por isso se trata de fazer dele um selvagem, de jogá-lo no fundo da floresta; mas que, entregue ao turbilhão social, basta que não se deixe arrastar pelas paixões nem pelas opiniões dos homens; que veja com seus olhos, que sinta com seu coração; que nenhuma autoridade o governe a não ser sua própria razão (ROUSSEAU, 1995, p. 291).

O papel principal deste processo é, assim como em Aristóteles, delegado à razão, é através do pensamento racional e do hábito, que o homem se tornará virtuoso nas práticas que estão em consonância com o bem comum. Em Rousseau, os valores cristãos e democráticos parecem se fundir, o bem comum é aqui retomado, aparecendo não apenas como fim, mas também como causa, através da vontade geral. A sua teoria educacional, desenvolvida no Emílio, fundamenta a formação de um cidadão que, apesar de movido pela razão, deve saber respeitar e compreender as vontades outras envolvidas no processo político, apenas porque segue os mesmos preceitos morais, apenas porque assim como os outros, tem como principal interesse o bem comum.

\section{Nietzsche, democracia e educação}

Um século mais tarde, Nietzsche escreve Além do Bem e do Mal. Esta obra, para além das diferenças estilísticas faz uma abordagem bastante distinta daquela realizada pelos autores anteriormente citados. A escrita nietzschiana

males como somos; virtude tanto mais universal e tanto mais útil ao homem quando nele precede o uso de qualquer reflexão, e tão natural que as próprias bestas às vezes dão delas alguns sinais perceptíveis" (ROUSSEAU, 1991a, p. 259).

Filosofia e Educação - ISSN 1984-9605

Volume 6, Número 2 - Junho de 2014 
não procura a todo momento a mesma exatidão e definição em seus termos, como tentam Aristóteles e Rousseau. Desde o início há uma preocupação por sugerir os sentidos que subjazem em certas expressões e ideias modernas. É nesse sentido que sua crítica à democracia e à educação modernas reside no ambiente de sua crítica à moral. Portanto, como o próprio autor diz, ele intenta fazer uma análise extramoral dos valores democráticos, expondo as origens e os sintomas das valorações morais que lhe subjazem, e aquilo que estas exercem na política, na ciência, na cultura. Inferindo assim, que o fim último deste processo é a produção em larga escala de homens úteis, adaptáveis, que se ajustem às demandas que o "progresso", assegurador da vida gregária e de suas relações internas, exige:

chama-se 'civilização', 'humanização' ou 'progresso' àquilo em que se vê a distinção dos europeus; chama-selhe simplesmente, sem louvar ou censurar, e utilizando uma fórmula política, o movimento democrático da Europa: por trás de todas as fachadas morais e políticas a que remetem essas fórmulas, efetua-se um tremendo processo fisiológico, que não pára de avançar - o processo de homogeneização dos europeus, seu crescente libertar-se das condições em que surgem as raças ligadas a clima e classe, sua independência cada vez maior de todo meio determinado, que durante séculos se inscreveria com exigências iguais no corpo e na alma ou seja, a lenta ascensão de um tipo de homem essencialmente supranacional e nômade, que fisiologicamente possui, como marca distintiva, o máximo em força e arte de adaptação (NIETZSCHE, 2005, p. 134. Grifo do autor).

Para Nietzsche, a moral que alimenta a democracia, esconde, por baixo de seus conceitos de bem comum, igualdade e liberdade, um processo contra a vida: é a negação do indivíduo singular, de seus afetos, de suas potencialidades, de sua diferença. Aquele que ousa querer ser senhor de si

Filosofia e Educação - ISSN 1984-9605

Volume 6, Número 2 - Junho de 2014 
mesmo, desprovido das amarras limitadoras da moral de rebanho, causa temor àqueles que foram formados para uma comunidade de iguais, de escravos que por um longo processo, que Nietzsche diz ser fisiológico, se tornam a cada dia mais especializados em sua igualdade e em sua utilidade aos desígnios da comunidade e, portanto, à manutenção das posições de senhor e de escravo ${ }^{8}$. Sobre este processo, assevera:

moral é hoje, na Europa, moral de animal de rebanho:logo, tal como entendemos as coisas, apenas uma espécie de moral humana, ao lado da qual, antes da qual, depois da qual muitas outras morais, sobretudo mais elevadas, são ou deveriam ser possíveis. Contra tal "possibilidade", contra tal "deveriam" essa moral se defende com todas as forças, porém: ela diz, obstinada e inexorável: "Eu sou a moral mesma, e nada além é moral!" - e, com a ajuda de uma religião que satisfez e adulou os mais sublimes desejos do animal de rebanho, chegou-se ao ponto de encontrarmos até mesmo nas instituições políticas e sociais uma expressão cada vez mais visível dessa moral: o movimento democrático constitui a herança do movimento cristão (NIETZSCHE, 2005, p. 89-90. Grifo do autor).

Como já dissemos, em Aristóteles e Rousseau havia uma preocupação principal: a manutenção da comunidade. A moral ajustada aos valores protetores da comunidade, que em Aristóteles travestiu-se como destino de todo homem (por sua natureza social) e como realização de uma felicidade coletiva, - já que a felicidade racional se acha no virtuosismo moral do cidadão - e que mais a frente, no Contrato Social, vai dar forma à vontade geral e ao bem comum que possibilitariam ao homem uma vida

8 Grifamos 'posições' a fim de destacar que o escravo e o senhor em Nietzsche não constituem 'naturezas' no sentido de determinações sociais inatas (e, destarte, metafísicas). Posições indica justamente a o fato de que o escravo e o senhor subsistem como arranjos vitais, como devires cuja marca fundamental é efemeridade, e, inclusive, a possibilidade aberta de sua alteração cuja melhor metáfora é a imagem do jogo. Cf. NIETZSCHE, Friedrich. Além do bem e do mal. São Paulo: Companhia das Letras, 2005. p. $172 \S 260$.

Filosofia e Educação - ISSN 1984-9605

Volume 6, Número 2 - Junho de 2014 
superior, mais uma vez através da razão, tais valores, segundo Nietzsche, são contrários à própria vida. Para tornar mais clara a distinção entre o homem proposto pelos valores democráticos, e aquele outro tipo esboçado em Além do Bem e do Mal, leiamos este trecho:

vocês querem, se possível (...) abolir o sofrimento; e quanto a nós? - parece mesmo que nós o queremos ainda mais, maior e pior do que jamais foi! Bem-estar, tal como vocês o entendem - isso não é um objetivo, isso nos parece um fim! Um estado que em breve torna o homem ridículo e desprezível - que faz desejar o seu ocaso! A disciplina do sofrer, do grande sofrer - não sabem vocês que até agora foi essa disciplina que criou toda excelência humana? (...) No homem estão unidos criador e criatura: no homem há matéria, fragmento, abundância, lodo, argila, absurdo, caos; mas no homem há também criador, escultor, dureza de martelo, deus-espectador e sétimo dia - vocês entendem esta oposição? (NIETZSCHE, 2005, p. 117-118. Grifo do autor).

Ao contrário de seus antecessores, aqui temos um filósofo que propõe um processo antes extramoral que moral, algo que se desloca de baixo para cima e não sempre de forma inversa, como proposto pelos seus antecessores. Em outro trecho ele reafirma esta cisão com a moral de rebanho, "o que é justo para um não pode absolutamente ser justo para outro, que a exigência de uma moral para todos é nociva precisamente para os homens elevados (...)" (NIETZSCHE, 2005, p. 121). Assim, ao nos voltarmos para os valores democráticos, tais como a igualdade e a liberdade, pela perspectiva apresentada por Nietzsche, estes valores passam a representar a mais alta submissão e escravidão expressas por uma moral de escravos. Quando, segundo ele, a sociedade deve servir apenas "como alicerce e andaime no qual um tipo seleto de seres possa elevar-se até sua tarefa superior e um modo de ser superior" (NIETZSCHE, 2005, p. 153), ou

Filosofia e Educação - ISSN 1984-9605

Volume 6, Número 2 - Junho de 2014 
seja, a estabilidade desta não é o fim para o qual deve tender os esforços do homem, pois a vida ultrapassa este tipo de contentamento: "a vida é essencialmente apropriação, ofensa, sujeição do que é estranho e mais fraco, opressão, dureza, imposição de formas próprias, incorporação e, no mínimo e mais comedido, exploração", e conclui: "terá de ser vontade de poder encarnada, quererá crescer, expandir-se, atrair para si, ganhar predomínio" (NIETZSCHE, 2005, p. 154-155).

$\mathrm{O}$ que temos aqui são valores opostos aos democráticos. Nietzsche não diz claramente como deve ser uma moral de um homem superior, e tampouco apresenta intenções finais para uma sociedade estável. Ao contrário, menciona processos inerentes à própria vida, que podem a qualquer momento ameaçar qualquer tipo de estabilidade política. Faz uma crítica da moral subjacente à democracia, expondo seu sentido extramoral; critica, portanto, o modelo de homem produzido por tais valores. E ao aludir o seu conceito de homem superior, não o parece colocar como fim de alguma moral, mas antes como uma possibilidade a ser engendrada pela vida mesma.

No sentido moderno, educação e cultura, enquanto sistemas destinados à formação do indivíduo, que deve corresponder a modelo moral e político, segundo Nietzsche, “(...) têm de ser, essencialmente, arte de enganar - enganar quanto à origem, quanto à plebe herdada no corpo e na alma" (NIETZSCHE, 2005, p. 164). Esta domesticação, transformação da massa em ferramenta útil aos interesses da sociedade, seria o estágio mais atual desta moral (democrática, de escravos, etc...), posta por Nietzsche como sendo a própria negação da vida.

Remontando ao contexto da Terceira Intempestiva - Schopenhauer como Educador, pode-se entrever uma retomada da crítica à moderna noção de formação (Bildung), posta em outras bases, mas ocupada - tal como à 
época - com uma contraproposta filiada aos aspectos assertivos de seu pensamento (como, por exemplo, a experimentação e a afirmação da vida). Conforme elucida Jorge Larrosa, "o modo como Nietzsche usa essa expressão nos diz qual é sua ideia da Bildung, e, mais ainda, nos dá indícios de como Nietzsche desmonta alguns dos pressupostos básicos dessa ideia tradicional e a faz explodir" (LARROSA, 2009, p. 09). Claro está que o conjunto de práticas ligadas à formação para a vida em uma sociedade dita democrática revelar-se-iam depauperantes aos olhos do filósofo alemão por justamente constituírem estratégias arrebanhadoras: o igualitarismo e a liberdade negativa (sob a égide do Estado). Tal como aduz em Zaratustra, ao indicar que a edificação do Estado moderno democrático está na razão direta da decadência da cultura, da autêntica formação de um povo:

Estado? Que é isto? Pois seja! Abri bem os ouvidos, porque, agora, vou dizer-vos sobre a morte dos povos. Chama-se Estado o mais frio de todos os monstros frios. E, com toda frieza, também mente; e esta mentira sai rastejando de sua boca: 'Eu, o Estado, sou o povo!' [...] Onde ainda existe um povo, este não compreende o Estado e o odeia como má sorte e uma ofensa aos costumes e à justiça (NIETZSCHE, 2003, p. 75).

Logo, as reflexões nietzschianas perfilam-se como notas dissonantes no itinerário melódico da tradição filosófica, uma vez que buscam associar os valores e condutas requeridos ao sujeito-cidadão, típicos do modelo educativo moderno essencialmente humanista e cristão, a instituição de um ethos doente porquanto represador e vituperador das potências vitais no humano. Na Contemporaneidade, deparamos com certas linhas de continuidade a despeito dos autores até então perquiridos, no trato filosófico de noções que se aproximam e se distanciam na medida em que explicitam ou ignoram certos aspectos da relação entre democracia e educação.

Filosofia e Educação - ISSN 1984-9605

Volume 6, Número 2 - Junho de 2014 
Schumpeter e a crítica à doutrina clássica da democracia

Em sua obra Capitalismo, Socialismo e Democracia, o economista e sociólogo tcheco Joseph A. Schumpeter, define a democracia como não sendo um fim em si mesmo, mas antes um meio para se chegar a uma decisão política. Schumpeter reforça que os valores considerados democráticos podem ser exaltados em outras formas de governo, bem como variam devido a fatores históricos.

A democracia é um método político, isto é, um certo tipo de arranjo institucional para chegar a uma decisão política (legislativa ou administrativa) e, por isso mesmo, incapaz de ser um fim em si mesmo, sem relação com as decisões que produzirá em determinadas condições históricas (SCHUMPETER, 1961, p. 291).

Com efeito, o autor assume que o sistema democrático coloca as asserções políticas como expoentes daquilo que os fatores histórico-sociais determinam. Ou seja, em certa medida o modo democrático de conduzir a política, pode possibilitar também que, valores até então não associados aos ‘ideais democráticos', se estabeleçam. Neste sentido, ela reflete os valores exaltados pelo povo.

A democracia, como qualquer outro método, não produz sempre os mesmos resultados nem favorece os mesmos interesses ou ideais. (...) Compreender a validez relativa de suas convicções e defendê-las resolutamente é justamente o que distingue o homem civilizado do bárbaro (SCHUMPETER, 1961, p. 292).

Outro ponto abordado por Schumpeter condiz à definição clássica de democracia como sendo governo do povo. Ele ressalta que apenas na democracia direta pode haver um governo do povo, em qualquer outro caso

Filosofia e Educação - ISSN 1984-9605

Volume 6, Número 2 - Junho de 2014 
há no máximo um governo aprovado pelo povo. Este é o argumento usado pelo autor para criticar as concepções de democracia postas pelos contratualistas dos séculos XVII e XVIII, segundo ele, os instrumentos teóricos não passavam de uma barganha, também usada séculos atrás, entre senhores feudais e homens livres, para que em troca de proteção e outras vantagens, os últimos passassem a ter obrigações econômicas e jurídicas com os primeiros.

Teríamos de conceber o povo, por conseguinte, como delegando seu poder, digamos a um parlamento, que o representaria. Mas apenas a pessoa física ou jurídica pode legalmente delegar ou ser representada. (...) Dizer que ele [o povo] delega poderes ou é representado por um parlamento é construir uma frase vazia de qualquer significado legal (SCHUMPETER, 1961, p. 298).

Em outras palavras, com a democracia dos contratualistas, a noção de forma de governo se alterava, seguindo o ritmo histórico, mas a concentração do poder de decisão permanecia distante do povo, pois sua principal ocupação teórica era com a estabilidade do Estado. Portanto, ao considerar a felicidade como princípio natural e racional das ações do cidadão:

ela evidentemente forneceu entre outras coisas, uma teoria da natureza do Estado e dos objetivos para os quais o Estado existe. Além disso, em virtude da importância que atribui ao indivíduo racional e hedonista e ao seu livre arbítrio, a filosofia em causa parece estar em condições de ensinar os únicos métodos políticos corretos de dirigir o Estado e concretizar seus objetivos - a maior felicidade para o maior número (...) (SCHUMPETER, 1961, p. 298).

Estas preocupações também apontavam para a necessidade de estruturação de um determinado arcabouço de valores já oferecidos pela 
noção grega de democracia, representados teoricamente pelo bem comum, vontade geral, soberania do povo, entre outros conceitos, que não faziam mais que colocar em prática o seguinte postulado: "educa o povo e deixa-o votar livremente" (SCHUMPETER, 1961, p. 299). Daí a importância do processo educacional que ao mesmo tempo em que educa para uma política de proteção do Estado, por meio de valores fixos e abstratos - os quais diante da mínima percepção histórica perderiam validade - instaura uma prática utilitarista ${ }^{9}$ que vai produzir aquele tipo humano nomeado por Nietzsche como animal de rebanho.

Sobre este processo, que colocou pouco a pouco o interesse político na mesma posição que os hobbies e outros assuntos de menor importância, Schumpeter considera: "sem a iniciativa que tem origem em responsabilidades imediatas, a ignorância persistirá, mesmo em face de uma massa de informações por mais completa e correta que ela seja" (SCHUMPETER, 1961, p. 313).

\section{A interdependência entre Democracia e Educação: Dewey e Teixeira}

O diagnóstico feito por Schumpeter, no fim do último tópico, nos encaminha para o espaço sobre o qual o filósofo norte-americano John Dewey se colocou para pensar a construção de uma sociedade democrática através da educação. Em sua obra Democracia e Educação, no capítulo intitulado 'A concepção democrática em educação', com vistas à apresentação de seu conceito de sociedade democrática, Dewey nos dá o seguinte exemplo sobre um determinado grupo social:

9 Cf. SCHUMPETER, J. Capitalismo, Socialismo e Democracia. Rio de Janeiro: Editora Fundo de Cultura, 1961. p. 298.

Filosofia e Educação - ISSN 1984-9605

Volume 6, Número 2 - Junho de 2014 
o isolamento e exclusividade de uma 'quadrilha' põe em realce o seu espírito antissocial. Mas este mesmo espírito se encontra onde quer que um grupo tenha interesses 'só seus' que o desviam de uma interação completa com outros grupos, de modo que o seu objetivo principal é a proteção do que obteve, em vez de se reorganizar e progredir em relações mais amplas. (...) O ponto essencial é que o isolamento contribui para a rigidez e institucionalização formal da vida, para os ideais estáticos e egoístas no grupo (DEWEY, 1995, p. 80-81).

Esta colocação inicial já nos remete diretamente a uma imagem de sociedade onde existem trocas entre grupos sociais distintos, entre indivíduos. Nesta perspectiva, Dewey, já esboça sua concepção de sociedade democrática, a qual considera como sendo aquela em que o indivíduo, na medida em que atua sobre determinada esfera de interesses, considera os interesses e ações dos outros para ponderar e direcionar as suas próprias. Para Dewey, a democracia não é apenas uma forma de governo, mas um modo de vida, ela se dá enquanto reflexão e comunicação sobre a vida partilhada. Neste sentido, ele concebe que este modo de conduzir a vida "é equivalente à quebra das barreiras de classe, raça, e território nacional que impede os homens de se aperceberem da plena significação de sua atividade" (DEWEY, 1995, p. 82). Sobre esta percepção do que é a vida partilhada, ou democrática, ele acrescenta:

onde quer que haja atividade conjunta cujas consequências sejam percebidas como boas por todas as pessoas singulares que participam dela, e quando a percepção do bem for tamanha a ponto de promover um desejo e esforço enérgico para mantê-lo justamente porque ele é um bem compartilhado por todos, há, em certa medida, uma comunidade. A consciência clara de uma vida comunitária, em todas as suas implicações, constitui a ideia de democracia (DEWEY, 2008, p. 40). 
É preciso dizer que este bem partilhado é de natureza completamente diferente daquele bem comum da doutrina clássica: aqui há uma inerente transformação associada ao movimento histórico. Dewey se refere a este termo como produto das relações de interdependência entre membros singulares (portanto, com interesses distintos) de uma comunidade. Os valores vigentes nessa comunidade têm sua legitimidade e origem na concretude das relações, pois, segundo o autor, é preciso partir de uma comunidade enquanto fato para perceber os seus elementos de modo a não cairmos na ideia utópica de democracia. Destarte,

em sua justa conexão com a experiência comunitária, a fraternidade é outro nome para os bens conscientemente percebidos que resultam de uma associação na qual todos compartilham e que dão direção à conduta de cada um. A liberdade é aquela liberação e realização segura das potencialidades pessoais que ocorrem somente na rica e múltipla associação com outros: o poder para ser um ser individualizado fazendo uma contribuição distintiva e desfrutando, do seu próprio modo, dos frutos da associação. A igualdade denota a parte não-tolhida que cada membro individual da comunidade tem nas consequências da ação associada. Ela é equitativa porque é medida apenas pela necessidade e capacidade de utilizar, não por fatores extrínsecos que privam um para que outro possa tomar e ter (DEWEY, 2008, p. 41).

Para o filósofo e pedagogo norte-americano, as conquistas democráticas como o sufrágio universal, a regra da maioria, entre outras formas assumidas pelo governo democrático, não tiveram como causa os ideais da doutrina clássica, e sim o desfecho irremediável de situações que precisavam ser solucionadas politicamente. Assim como Aristóteles, Dewey considera o homem um animal social, mas diferentemente do primeiro, explicita o caráter singular de cada cidadão e designa o bem partilhado como distinto daquele de natureza particular. Tendo em vista essa dimensão 
individual, o autor reflete sobre o papel da educação como prática da vivência comunitária, defendo que "os jovens precisam ser criados dentro das tradições, perspectivas e interesses que caracterizam uma comunidade por meio da educação: através de instrução constante e de aprendizado em conexão com os fenômenos de associação", e, dessa perspectiva, arremata:

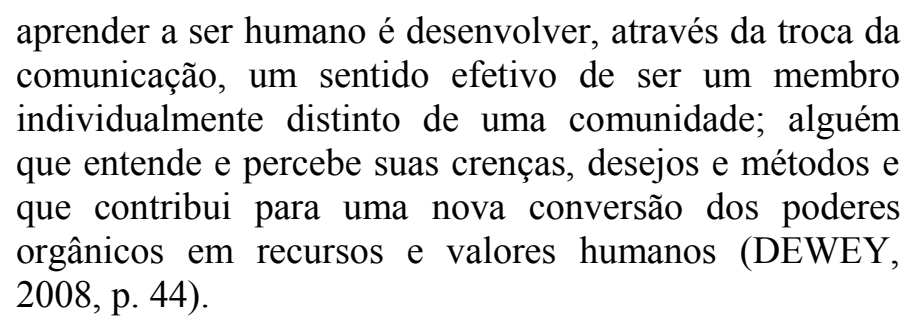

Para promover tal emancipação afetiva e intelectual, é necessária uma total reformulação do modelo educacional vigente. Ao reafirmar a educação como base de uma sociedade democrática, Dewey insiste que até agora esta condição não foi realizada com rigor, e conclui: “(...) o fim da democracia é um fim radical. Pois ele é um fim que não foi adequadamente realizado em país algum e em época alguma. Ele é radical porque requer uma enorme mudança nas instituições sociais, econômicas, jurídicas e culturais existentes" (DEWEY, 2008, p. 111-112). A origem da mudança radical, acenada por Dewey, precisa se dar no indivíduo para alcançar as instituições, aí se encontra a principal dificuldade, posto que a instituição democrática por excelência precisa ser a escola, no entanto sabemos que esta tem sua estrutura definida e atravessada pelos interesses ${ }^{10}$ do Estado.

No Brasil, o pensador Anísio Teixeira, no fim da década de 1950, se propôs a pensar o modelo de escola democrática no seu ensaio intitulado Democracia e educação: o processo democrático da educação, profundamente influenciado pelas ideias de Dewey. Nele, o autor inicia 10 Cf. Ibid., p. 298.

Filosofia e Educação - ISSN 1984-9605

Volume 6, Número 2 - Junho de 2014 
alertando que nenhuma instituição é natural, logo, para se promover uma educação democrática é preciso que haja um planejamento estrutural e intencional comprometido com a produção do modo de vida democrático.

Segundo Teixeira, é imperativo que hajam condições adequadas não apenas para que todos possam desenvolver suas qualidades, mas também para que possam realizá-las em igualdade de condições. Pois, na medida em que se abandona o modelo individualista para poucos (da doutrina clássica) - e consequentemente um modelo aristocrata de escola - para se chegar ao individualismo para muitos, é preciso que a escola, rigorosamente pensada, possibilite a inserção dos cidadãos nas esferas públicas onde ocorrem as decisões políticas. Portanto, o modelo democrático precisa vir da própria estrutura funcional da escola. Tal como sustenta, "a escola é uma comunidade com seus membros, seus interesses, seu governo. Se esse governo não for um modelo de governo democrático, está claro que a escola não formará para a democracia" (TEIXEIRA, 1969, p. 4). Antecipando o que vem se compreendendo nas últimas duas décadas como gestão escolar participativa ou democrática, o autor brasileiro versa sobre o dever de participação dos atores escolares (diretores, professores e alunos) na tarefa de governar a escola, mediante um indispensável sentimento de interesse compartilhado por todos.

Percebemos assim uma escola orientada para a experiência comunitária $^{11}$, onde o saber já não aparece como algo contraposto à realidade, pelo contrário, Teixeira fala que esta escola se destina ao saber das coisas, e não ao saber sobre as coisas. Isto significa que a escola se torna uma instituição responsável por um processo de reapropriação das

11 Nessa direção, Teixeira coloca-se em conformidade com o princípio nodal da filosofia da educação deweyana: "considero que a unidade fundamental da nova Filosofia da Educação tem como base a ideia de que há uma relação íntima e necessária entre os processos da experiência real com a educação" (DEWEY, 2010, p. 22). 
experiências do indivíduo, no sentido de "reconstruí-las e integrá-las em uma experiência mais larga, em que se destruam os isolamentos artificiais e as prevenções segregadoras, visando o estabelecimento de uma verdadeira fraternidade humana" (TEIXEIRA, 1969, p. 5). Ele insiste, que o indivíduo ao se dar conta de que é por meio das instituições sociais que o homem amplia e realiza sua liberdade, irá respeitá-las e buscará no saber a continuidade dos seus esforços para reforçá-las enquanto espaços democráticos. Para tanto, o modelo escolar precisa abarcar toda a população, uma vez que

a democracia não pode existir sem educação para todos e cada um, pois importa em transformar, não alguns homens, mas todos os homens para - contra tendências hereditárias, sociais, se não biológicas - rematar, por evolução consciente, a obra que as sucessivas civilizações, desde o começo dos séculos vêm realizando pela injustiça e consequente violência. Todas as outras formas de sociedade precisam de alguma educação, mas só a democracia precisa de educação para todos e na maior quantidade possível... (TEIXEIRA, 1969, p. 11).

Assim, a educação democrática precisa ser compreendida, nas palavras de Teixeira, não como mera atividade a ser incluída no currículo escolar, mas acima de tudo enquanto "'modo' de conduzir as atividades do ensino e da vida extraclasse para a formação do indivíduo na sociedade democrática" (TEIXEIRA, 1969, p. 10).

\section{Ideia de uma educação democrática a partir de Paulo Freire}

Herdeiro de diversas correntes filosóficas do século XX (marxismo ocidental, personalismo, filosofias da existência, entre outras), Paulo Freire é um daqueles pensadores que podem ser colocados entre os principais defensores de uma concepção de educação que filia umbilicalmente a 
atividade democrática a uma prática pedagógica libertadora. Esse motivo fundamental não é encontrado em uma obra específica do pedagogo brasileiro, mas anima praticamente toda a sua produção intelectual, como um de seus elementos mais determinantes.

$\mathrm{Na}$ Pedagogia do Oprimido, o autor apresenta a dinâmica de opressão que está ligada à forma como o fenômeno educativo é vivenciado nas sociedades capitalistas periféricas. Para ele, a conscientização dos povos subalternizados acerca de sua própria situação de explorado é condição necessária à realização da práxis emancipatória, mediada por uma educação problematizadora, a qual coloca os envolvidos no processo pedagógico como iguais - e, portanto, em conformidade com um evidente princípio democrático - sob a égide do diálogo:

o educador já não é mais o que apenas educa, mas o que enquanto educa, é educado, em diálogo com o educando que ao ser educado, também educa. Ambos, assim, se tornam sujeitos do processo em que crescem juntos e em que os 'argumentos de autoridade' já não valem (FREIRE, 2005, p. 68).

Conforme Freire, 'argumentos de autoridade' característicos de uma experiência educativa assimétrica e de um modelo de vida social e econômica repressor devem ser combatidos por uma pedagogia de viés democrático que viabilize a ininterrupta problematização da realidade, construindo assim os meandros para a sua superação. Nesse sentido, a noção freireana de democracia (essencialmente articulada àquela afirmada por Dewey $^{12}$ e Teixeira ${ }^{13}$ ) é muito mais abrangente que a simples ideia de

12 Conforme Dewey, "democracia é mais do que uma forma de governo; é, essencialmente, uma forma de vida associada, de experiência conjunta e mutuamente comunicada" (DEWEY, 1979, p. 93).

13 Para Teixeira, "democracia é acima de tudo o modo moral da vida do homem moderno" (TEIXEIRA, 1975, p. 41).

Filosofia e Educação - ISSN 1984-9605

Volume 6, Número 2 - Junho de 2014 
modelo de governo. De acordo com ele, "a democracia que, antes de ser forma política, é forma de vida, se caracteriza, sobretudo por forte dose de transitividade de consciência no comportamento do homem", e remata ao dizer que esta "não nasce e nem se desenvolve a não ser dentro de certas condições em que o homem seja lançado ao debate, ao exame de seus problemas e dos problemas comuns. Em que o homem participe" (FREIRE, 2007, p. 81).

Tal participação se dá ao mesmo tempo em que há a compreensão da autonomia por parte dos sujeitos que se veem como iguais do ponto de vista da capacidade de entrar no debate público, discutir suas condições de vida, e, sobretudo, transformá-las pela práxis, na busca por sua liberdade. Esta que ao passo que é buscada é também conquistada através do livre expressar-se o qual é inerente à dinâmica própria de contextos democráticos. Ademais, Freire entende que a verdadeira participação popular deve ultrapassar o mero caráter colaborativo e representativo entre povo e administração pública, na consecução de uma experiência democrática autêntica, a qual demanda os poderes de eleger prioridades, escolher e decidir, para além do ‘já programado’ estabelecido pelos governos. Em suas palavras,

uma compreensão autoritária da participação a reduz, obviamente, a uma presença concedida das classes populares a certos momentos da administração. Para nós, também, é que os conselhos de escola têm uma real importância enquanto verdadeira instância de poder na criação de uma escola diferente. Participação popular para nós não é um slogan mas a expressão e, ao mesmo tempo, o caminho da realização democrática (FREIRE, 2000, p. 75).

O exemplo do conselho escolar na gestão das instituições de ensino liga-se em profundidade às teses pedagógicas freireanas. É em razão de uma 
pedagogia que se pode denominar democrática porquanto fundada no diálogo, na liberdade, na criticidade, na autonomização dos envolvidos, na escuta do alteridade, no respeito às diferenças, que se torna possível a experiência democrática de um povo. Como escreve em Pedagogia da Autonomia, "a solidariedade social e política de que precisamos para construir a sociedade menos feia e menos arestosa, em que podemos ser mais nós mesmos, tem na formação democrática uma prática de real importância" (FREIRE, 2008, p. 28).

A Educação de Jovens e Adultos constitui certamente a mais significativa contribuição do pensamento de Paulo Freire em direção a essa experiência tanto no Brasil como na América Latina e em África. De fato, o que se quer com a adoção da prática educativa democrática libertadora é a restauração da cidadania enquanto cidadania crítica, capaz de promover a saída da condição de subalternos, eivada pela consciência histórica do próprio inacabamento humano. Assim sendo, o processo de alfabetização ao possibilitar "uma leitura crítica da realidade, se constitui como um importante instrumento de resgate da cidadania que reforça o engajamento do cidadão nos movimentos sociais que lutam pela melhora da qualidade de vida e pela transformação social" (FREIRE, 2000, p. 68).

Com Paulo Freire percebemos que, em primeiro lugar, a democracia não se reduz a uma forma de governo, mas sim a um modo fundamental de experimentação da vida social; em segundo lugar, a construção de uma sociedade mais igualitária, na qual possam efetivar-se de modo objetivo os elementos da justiça social, requer essencialmente um modelo educativo que privilegie a democracia e ao mesmo tempo forme para uma decidida convivência cidadã; em terceiro lugar, o caráter pedagógico da democracia forjaria inclusive o reconhecimento dos oprimidos, desassistidos e das 
minorias, em torno de sua condição, possibilitando a conquista radical do que o autor chama 'democracia substantiva': "as chamadas minorias, por exemplo, precisam reconhecer que, no fundo, elas são a maioria"; e entregando uma chave, escreve o autor: "o caminho para assumir-se como maioria está em trabalhar as semelhanças entre si e não só as diferenças e assim, criar a unidade na diversidade, fora da qual não vejo como aperfeiçoar-se e até como construir-se uma democracia substantiva, radical" (FREIRE, 1994, p. 154).

Compreendemos até então que o estado de coisas do mundo capitalista burguês, que se mantém através de dinâmicas de desumanizaçãoopressão das massas, é o alvo de uma educação que se pretende emancipatória, porque desde sempre vivida à luz da democracia. No cerne da pedagogia freireana, o elemento democrático é indispensável à realização da libertação, mas, ao mesmo tempo, é construído e compartilhado dentro dele. Logo, apenas um aprendizado democrático é capaz de promover em termos de lutas sociais das camadas populares (e aqui Freire segue uma tendência marxista) a democracia mesma como uma conquista: "não se recebe a democracia de presente. Luta-se pela democracia. Não se rompem as amarras que nos proíbem de ser como uma paciência bem comportada, mas com o Povo mobilizando-se, organizando-se, conscientemente crítico" (FREIRE, 2000, p. 117).

Por conseguinte, é possível afirmar que tanto nas meditações freireanas como em seu método de alfabetização verifica-se claramente uma interdependência entre educação e democracia enquanto antídoto contra toda forma de 'educação bancária', conformista e mistificadora da realidade histórica. Igualmente, pode-se considerar que assim como nas reflexões sobre educação na contemporaneidade predomina a visão segundo a qual 
elementos democráticos devem ser inerentes às práticas educativas, inclusive a fim de justificá-las, é inteiramente factível que tais práticas efetivamente já venham tomando corpo nas últimas décadas, contaminando as experiências educativas que vão da vida familiar à escolar. No entanto, não acreditamos que isso se realize sem a tensão e o tempo caracterizadores das grandes mudanças sociais.

\section{Últimas considerações}

Como podemos ver, Aristóteles institui a necessidade da estruturação de um sistema educacional público, que forme cidadãos em conformidade com a forma de governo da polis. Nesse contexto, a democracia não deve ser só um método político, mas um conjunto de valores e práticas que são incutidos no cidadão pela sua formação moral e intelectual, formação esta que tem como articulador principal a razão. Estes valores, tais como a liberdade, a igualdade e sua consequência, o bem comum, vão permanecer, não obstante as transformações sofridas com o advento do cristianismo e o crescimento e expansão das cidades, como princípios fundantes do ideal democrático. Já em Rousseau, temos um corpo político que, embora mais complexo em suas instituições - por conta das transformações sofridas pela implementação da democracia em grandes Estados - continua com feições e práticas já estabelecidas por Aristóteles.

Os ideais democráticos defendidos por Rousseau passam a constituir o cerne das práticas políticas dos Estados. É por meio da igualdade de direitos, do virtuosismo moral, da soberania do povo e dos desígnios da vontade geral que se solidificam as bases da estrutura política proposta no Contrato, em franca correspondência com as teses do Emílio, onde reafirma o ideal de cidadão aduzido em sua obra política. Segundo Rousseau, o 
cidadão é aquele que busca acima de tudo o bem estar social (bem comum), que o levará a uma vida superior que tem a razão e os princípios e práticas morais como seus condutores, os quais só se tornam possíveis mediante um modelo naturalista de educação que catalise a bondade natural do homem, reverberando-a para a vida social.

Esta relação na qual a educação e a cultura servem sempre para a formação de indivíduos adequados a determinado quadro de valores vigentes - outrora políticos, sociais e religiosos, agora acima de tudo, econômicos - será duramente criticada por Nietzsche como sendo uma espécie de falsificação, de engano tornado hábito e modo de vida para produzir homens úteis à manutenção de formas decadentes de existência. Numa palavra: niilismo. Ao criticar fortemente os valores democráticos, já que estes seriam valores que degeneram a vida, e que, portanto, se contrapõem à nobreza de espírito ao proporem a igualização dos homens através de uma moral única, cristã em sua consolidação, rasa e efêmera enquanto cultura que ignora suas origens, Nietzsche se coloca nos antípodas e ao mesmo tempo contribui com abertura de uma outra senda interpretativa da noção de democracia à posteridade filosófica, bem como das acepções de educação a ela filiadas.

Os ideais democratas, forjados ainda na Grécia antiga, transformaram-se, assumiram outras formas de funcionamento no mundo contemporâneo. Desde a crítica nietzschiana à democracia utilitarista concebida pelos contratualistas - que privilegia a estabilidade do Estado em detrimento do indivíduo singular - buscou-se compreender de que maneira as formas assumidas por esse regime de governo poderiam se integrar à democracia percebida enquanto método, e não mais enquanto fim (telos). 
Nesse sentido, é possível enxergar certas linhas de continuidade entre a crítica nietzschiana e a análise de Schumpeter ${ }^{14}$.

$\mathrm{O}$ autor tcheco enfatiza a inexequibilidade histórica de efetivação de um 'poder do povo', sustentando haver unicamente grupos detentores de poder que se alternam dentro das próprias democracias (nos trilhos da teoria das elites de Gaetano Mosca e Vilfredo Pareto). Por esse e outros motivos, insiste em pensar que o único regaço argumentativo possível à democracia é concebê-la como forma de decisão política, destituindo-a da parafernália moral, axiológica e religiosa que a sempre ela esteve atrelada. Noutra via, Schumpeter nos permite compreender o papel que a educação teria na proteção do Estado e, por sua vez, do conjunto de valores que o asseguram. Contudo, mesmo dizendo de forma indireta, aponta para o processo de formação do indivíduo como lugar também da formação da consciência política. Esta alusão é desenvolvida por Dewey na sua concepção de democracia como modo de vida, e da escola como lugar da vivência democrática, pois segundo ele, só através da experiência do fazer seria possível exercer, de fato, não só individualmente mas também através das instituições sociais, a verdadeira democracia. Deste modo, os ideais democráticos deixam o reino ideal e se aninham aos processos reguladores do modo de vida associativo.

No Brasil, Anísio Teixeira e Paulo Freire, na esteira das concepções deweyanas, pensam o processo educacional brasileiro como procedimento que busca emancipar indivíduos pertencentes a uma realidade social extremamente desigual. Neste sentido, a educação democrática, ao envolver o indivíduo num modo de vida comunitário dentro da própria escola,

14 Cf. APOLINÁRIO, José Antônio Feitosa. A crítica nietzschiana à democracia e suas possíveis consonâncias contemporâneas. Argumentos. Fortaleza: UFC, Ano 4, $\mathrm{n}^{\mathrm{o}} 8$, jul./dez., p. 210-221, 2012.

Filosofia e Educação - ISSN 1984-9605

Volume 6, Número 2 - Junho de 2014 
problematiza o espaço partilhado, produzindo no indivíduo uma responsabilidade política para com aqueles com os quais partilha o comum. A escola é apenas o início; todavia, neste começo de século XXI, sobretudo em nosso país, a democracia ainda encontra dificuldades em edificar-se.

Antes de quaisquer conclusões fechadas, gostaríamos de frisar que este é um trabalho que não cessa. Apesar de termos adentrado no pensamento de alguns autores contemporâneos, de conseguirmos notar relações de continuidade e ruptura entre os teóricos, entendemos que pela complexidade das relações entre democracia e educação, e em razão da extensa gama de elementos envolvidos neste campo, seria praticamente impossível traçar um diagnóstico que pudesse abarcar satisfatoriamente a situação em que nos encontramos. Isto dito, intentamos ao menos ressaltar alguns aspectos para um futuro diagnóstico mais completo, o que não significa dizer acabado.

\section{Referências}

APOLINÁRIO, José Antônio Feitosa. A crítica nietzschiana à democracia e suas possíveis consonâncias contemporâneas. Argumentos. Fortaleza: UFC, Ano 4, no 8, jul./dez., p. 210-221, 2012.

ARENDT, Hannah. Entre o passado e o futuro. Tradução de Mauro W. Barbosa. São Paulo: Perspectiva, 2011.

ARISTÓTELES. Política. Trad. de Márcio da Gama Kury. Brasília: Editora Universidade de Brasília, 1985.

BOBBIO, Norberto; MATTEUCCI, Nicola; PASQUINO, Gianfranco. Dicionário de política. 11. ed. Brasília: Editora Universidade de Brasília, 1998.

DAHL, Robert A. La democracia y sus críticos. Barcelona: Ediciones Paidós Ibérica, 1992.

DEWEY, John. Democracia e educação. Tradução de Godofredo Rangel e Anísio Teixeira. São Paulo: Nacional, 1979.

Filosofia e Educação - ISSN 1984-9605

Volume 6, Número 2 - Junho de 2014 
Democracia y educación. Madrid: Ediciones Morata, 1995.

Democracia cooperativa: Escritos Políticos Escolhidos de John Dewey

(1927-1939). Conferência Mundial sobre o Desenvolvimento de Cidades. Porto

Alegre: Augusto de Franco e Thamy Pogrebinschi, 2008.

. Experiência e educação. Tradução de Renata Gaspar. Petrópolis: Vozes,

2010.

FREIRE, Paulo. A educação na cidade. 4. ed. São Paulo: Cortez, 2000.

. Educaşão como prática da liberdade. 30. ed. Rio de Janeiro: Paz e Terra,

2007.

. Pedagogia da autonomia. 38. ed. São Paulo: Paz e Terra, 2008.

Pedagogia da esperança: um reencontro com a Pedagogia do oprimido.

3. ed. Rio de Janeiro: Paz e Terra, 1994.

. Pedagogia do oprimido. 47. ed. Rio de Janeiro: Paz e Terra, 2005.

HOUDARKIS, Antoine. Aristóteles e a educação. Tradução de Luiz Paulo

Rouanet. São Paulo: Loyola, 2001.

LARROSA, Jorge. Niețssche e a educação. Tradução de Semíramis Gorini da

Veiga. 3. ed. Belo Horizonte: Autêntica, 2009.

NEDERMAN, Cary J. The puzzle of the political animal: nature and artifice in

Aristotle's political theory. The review of politics. South Bend, Vol. 56, No. 2, p.

283-304, 1994.

NIETZSCHE, Friedrich. Além do bem e do mal: prelúdio a uma filosofia do futuro. Trad. de Paulo César de Souza. São Paulo: Companhia das Letras, 2005.

Assim falou Zaratustra. Tradução de Mário da Silva. 12. ed. Rio de Janeiro: Civilização Brasileira, 2003.

ROUSSEAU, Jean-Jacques. Discurso sobre a origem e os fundamentos da desigualdade entre os homens. Trad. de Lourdes Santos Machado. 5. ed. São Paulo: Abril Cultural, 1991. Col. Os Pensadores. (1991a). . Do contrato social. Trad. de Lourdes Santos Machado. 5. ed. São Paulo:

Abril Cultural, 1991. Col. Os Pensadores. (1991b). . Emilio ou da educação. 3. ed. Rio de Janeiro: Bertrand Brasil, 1995.

SCHUMPETER, Joseph. Capitalismo, socialismo e democracia. Tradução de Ruy Jungmann. Rio de Janeiro: Editora Fundo de Cultura, 1961.

Filosofia e Educação - ISSN 1984-9605

Volume 6, Número 2 - Junho de 2014 
TEIXEIRA, Anísio. Pequena introdução à filosofia da educação. São Paulo: Nacional, 1975.

Democracia e educação: o processo democrático da educação. In: Educação e o mundo moderno. São Paulo: Ed. Nacional, 1969.

VIEIRA, Luiz Vicente. A democracia em Rousseau: a recusa dos pressupostos liberais. Porto Alegre: EDIPUCRS, 1997. 